\title{
Efficacy of Trichoderma harzianum as A Bio-control Agent Compared with Traditional Chemical Fungicide for Controlling the Soil Borne Pathogen (Fusarium oxysporum f. sp. Lycopersici) Infesting Tomato Plants
}

\author{
Zen-El-Dein, Manal M. ${ }^{1}$; R.A. Hendi ${ }^{2}$ and A.S. Abo-Shanab ${ }^{1}$ \\ ${ }^{1}$ Central Agricultural Pesticides Laboratory, ${ }^{2}$ Plant Protection Research Institute, \\ Agricultural Research Center, Egypt \\ Corresponding author : Zen-El-Dein, Manal, e-mail: manzen67@gmail.com
}

\begin{abstract}
Laboratory and greenhouse experiments were conducted to investigate the efficacy of a biological control agent (Trichoderma harzianum) against the soil-borne plant pathogen (Fusarium oxysporum f. sp. Iycopersici) as compared with a traditional fungicide (Vitavax $\left.{ }^{\circledR}-200\right)$. Results indicated that $T$. harzianum was more effective than Vitavax ${ }^{\circledR}-200$ for radial growth inhibition. Through seedling dip and soil application, Vitavax ${ }^{\circledR}-200$ was more effective than $T$. harzianum where it recorded the least wilt incidence comparing to untreated control, but it gave a shorter height of tomato plant than $T$. Harzianum with significant differences between them. Also, application of $T$. harzianum as antagonistic agent significantly increased the plant height and increased fruit yield/plant without significant differences with Vitavax ${ }^{\circledR}$ when compared with untreated control.
\end{abstract}

Keywords: Trichoderma harzianum, Disease severity, soil-borne plant pathogen, Fusarium oxysporum.

\section{INTRODUCTION}

Tomato (Lycopersicon esculenturn Mill) is one of the most important Solanaceous economic vegetable crops in Egypt for local consumption and exportation. Its popularity is due to its high nutritive value, diversified use, and nutritional significance as a source of vitamins $A$ and $C$. It is affected by several diseases, reflecting negatively on plant growth and the produced yield (Anonymous, 2007). Fungal pathogens are considered as damaging agents causing a considerable reduction of its production.

The wilt disease caused by the soil-borne fungi [Fusariurn oxysporum $\mathrm{f}$. $\mathrm{sp}$. Lycopersici (Sace.)] has serious effects on tomato plants either in nurseries or in the fields (Besri, 1982). It remains to be a challenging task in terms of management, because of nature, application of fungicides to control this disease is not practical. Besides, chemicals pose serious health hazards to the applicator as well as to the consumer.(Agrios, 2005;Srinonet al., 2006 and Cal et al., 2004).In addition to target organism, pesticides also kill various beneficial organisms. Their toxic forms persist in soil and contaminate the whole environment (Hayes and Laws, 1991).

Trichoderma species that are common inhabitants of the rhizosphere are useful as they can be used as biological control organisms against a wide range of soil borne pathogens and also have been known to provide plant growth promotion. Successful reductions of Fusarium wilt in many crops with application of different species of Trichoderma have been found (Bell et al., 1982; Elad and Kapat, 1999 and Ramezani 2009). However, it is also reported that all the isolates of Trichoderma spp. are not equally effective in control of pathogen in vitro (Biswas and Das, 1999 and Ramezani, 2008) and in vivo 
conditions to control diseases. Therefore, $T$. harzianum gave a successful control of a particular pathogen. $T$. harzianum Rifai have been known to show antagonism to various root pathogens such as Pythium spp., Rhizoctonia spp. and Fusarium spp. (Baker, 1989 and Chet et al., 1987) and has been described as a most promising biocontrol agent, (Morsy et al., 2009 and Sabalpara et al., 2009). Some strains of $T$. harzianum establish robust and long lasting colonization of root surfaces penetrating into the epidermis (Harman, 2000). This colonization by $T$. harzianum frequently enhances root growth development, crop productivity and resistance to abiotic stresses through enhancement of mineral absorption.

Therefore, the objectives of the present study were to assess the ability of $T$. harzianum as a bio-control agent in suppressing the populations of Fusariurn oxysporum f. sp. Lycopersici (Sace.) in tomato under in vitro and in vivo conditions, comparing with standard chemical traditional fungicide [Vitavax ${ }^{\circledR}-200$ $75 \%$ WP] which has been recommended by the Egyptian Ministry of Agriculture.

\section{MATERIALS AND METHODS}

Tested fungi were : Fusariurn oxysporum f. sp. Lycopersici (Sace.) and T. harzianum obtained from the Plant Pathology Institute laboratory, Agricultural Research Center, Egypt.

Tested chemical : [Vitavax ${ }^{\circledR}-200(37.5 \%$ Carboxin $+37.5 \%$ thiram $)$ ] was also obtained from Central Agricultural Pesticide Laboratory, Agricultural Research Center, Egypt.

In vitro comparing effect of $T$. harzianum antagonist and a traditional fungicide (Vitavax $\left.{ }^{\circledR}-200\right)$ against F. oxysporum f. sp. lycopersici pathogen

The tested fungi were placed and cultured on potato dextrose agar (PDA) medium separately, and incubated at the laboratory conditions at $25^{\circ} \mathrm{Cfor} 4$ days for $T$. harzianum and 7 days for $F$. oxysporum f. sp. lycopersici. Nine millimeters discs of fifteen days old $F$. oxysporum fungal culture were placed on PDA medium one $\mathrm{cm}$ away from the edge of the plate, separately and anther (9 $\mathrm{mm}$ ) disc of $T$. harzianum or traditional fungicide (Vitavax ${ }^{\circledR}-200$ ) were placed at the opposite side of the petri plate. Four replicated plates for each treatment was maintained and incubated at $25^{\circ} \mathrm{C}$. Inhibition percentage over control was calculated (Vincent, 1927) as the following formulae :

$$
\mathrm{IP}=\frac{\mathrm{C}-\mathrm{T}}{\mathrm{C}} \mathrm{X} 100
$$

Where :IP = Inhibition percentage over control, $C=$ Growth of tested pathogen with absence of antagonist $(\mathrm{mm})$ and $\mathrm{T}=$ Growth of the tested pathogen with antagonist $(\mathrm{mm})$

Greenhouse experiment: A field experiment was conducted to test the efficacy of T. harzianum and Vitavax ${ }^{\circledR}-200$ against $F$. oxysporum f. sp. lycopersici. Soil Mixture (clay: sand1:1 w/w) was prepared and autoclaved for $1 \mathrm{hr}$ for two consecutive days and was put in plastic pots of $5 \mathrm{~kg}$ capacity. Tomato (supper strain B) seeds were sown in autoclaved soil mixture in the plastic pots. After 25 days, the seedlings were pulled out from the pots and washed in tap water then 
immersed in the T. harzianum conidial suspension $\left(10^{7} / \mathrm{ml}\right)$ or dipped in the Vitavax ${ }^{\circledR}-200$ solution $(0.15 \%)$, ensuring that the roots alone were immersed in the solutions and then transplanted in pots at the rate of four seedlings per pot ( $5 \mathrm{~kg}$ capacity which were infested with the wilt pathogen $F$. oxysporum f. sp. lycopersici at a concentration of $10^{7}$ conidia/ml allowed to establish in the soil for a period of 6 days.). Soil drenched with treatments after 15 and 30 days of transplantation.

Disease severity (DS) assessment was done 21 days after transplanting when symptoms of infection were observed. Such symptoms included clearing of the veins and drooping of petioles followed by yellowing of lower leaves (Agrios, 1988). Four plants were selected at random, marked with pieces of string and were used to evaluate disease severity after every 3 weeks. Disease severity was determined using a modification of a scale proposed and designed by Waudo et al., (1995). This was based on the wilt severity rated as follows; (\% of shoot wilted, using a scale of $0-5$ where, $0=$ No symptoms, $1=$ One leaf wilted (1\%-25\%), $2=2$ or 3 leaves wilted (26\%-49\%), 3=half plant wilted (50\%-74\%), 4= all leaves wilted (75\%-100\%) and 5=Plant dead). Four seedlings from treatments had their roots were stained by the method of Kormaik and McGraw (1982).

The observation on the disease incidence percentage was recorded at the harvest time. Each treatment was replicated six times in Completely Randomized Block Design (CRBD).Table 1 shows the treatments details.

Table (1) : The treatments of the biological control agent and the fungicide Vitavax $^{\circledR}-200$

\begin{tabular}{|c|c|}
\hline Treatments & Treatment details \\
\hline Trichoderma harzianum & Seedling dip at $0.2 \%+$ Soil application at 15 and 30 DAT*at $0.2 \%$ \\
\hline Vitavax ${ }^{\circledR}-200(0.15 \%)$ & Seedling dip at $0.15 \%+$ Soil drenching at 15 and 30 DAT at $0.15 \%$ \\
\hline Inoculated control & (with pathogen) \\
\hline Healthy control & (without pathogen) \\
\hline
\end{tabular}

*DAT : day after treatment

Severity of infection and treatment efficacy percentages were recorded as loss of weight according to the equation suggested by Spalding and Reeder (1974) :

DI $($ Disease Index \%) = (No. of leaves wilted / Total No. of leaves $) \times 100$

Statistical analysis: The data were statistically analyzed and the treatment means were compared by Duncan's Multiple Range Test (DMRT) (Gomez and Gomez, 1984). 


\section{RESULTS AND DISCUSSION}

The efficiency of the tested treatments (In vitro) on the radial mycelial growth of F. oxysporum f. sp. lycopersici

T. harzianum and Vitavax ${ }^{\circledR}-200$ weretested for their in vitro effect against F. oxysporum f. sp. Lycopersici by traditional dual cultural technique.

The obtained data in Fig. (1) indicated that $T$. harzianum inhibited the mycelial growth of $F$. oxysporum f. sp. lycopersici to an extent of $79.0 \%$ over control followed by traditional fungicide Vitavax ${ }^{\circledR}-200$ by $64.0 \%$ radial growth inhibition. There for, the bio-control agent ( $T$. harzianum) was more effective than the traditional fungicide in inhibiting the radial growth of $F$. oxysporum.
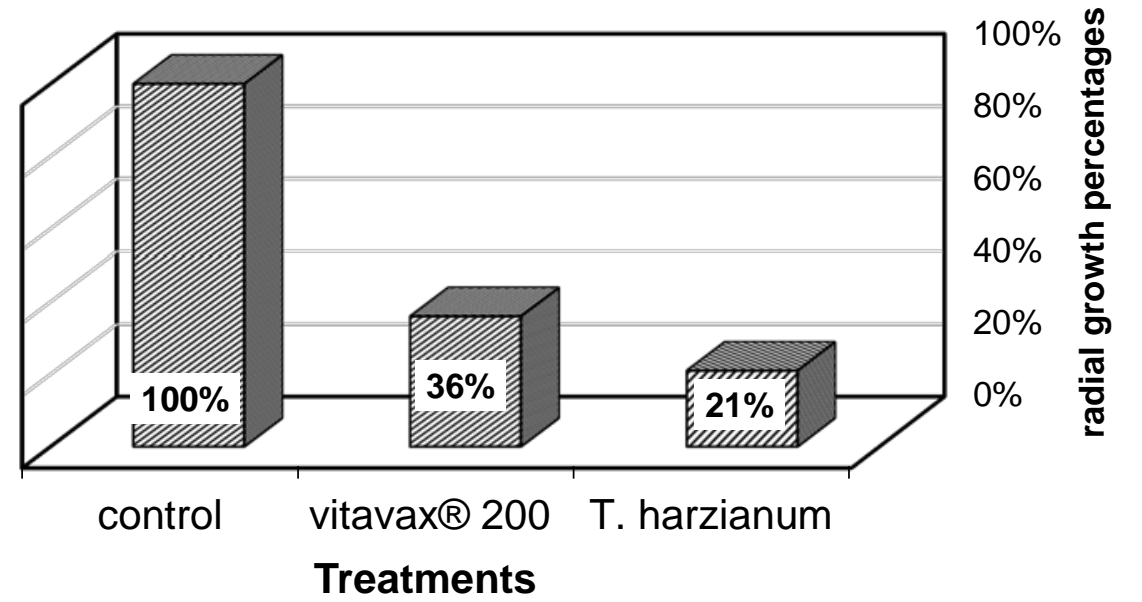

Fig. (1) : Soil-borne fungus F. oxysporum f. sp. Lycopersici radial growth percentages affected by tested bio-control agent and traditional fungicides Vitavax ${ }^{\circledR}-200$.

Effectiveness of $T$. harzianum antagonist on wilt incidence and yield parameters under glasshouse conditions

Obtained data in Table (2) showed that application of $T$. harzianum antagonist through seedling dip and soil application was effective in suppressing wilt incidence giving a disease incidence percentage of $16.9 \%$. It was clear that Vitavax ${ }^{\circledR}-200(0.15 \%)$ was found to be more effective than $T$. harzianum, where it recorded the least wilt incidence of $11.3 \%$ compared to untreated control, but it gave a shorter height of tomato plant than T. Harzianum $(62.4 \mathrm{~cm})$ with significant differences between them. Also, the results of this experiment revealed that the application of $T$. harzianum antagonistic agent significantly increased the plant height (by $15.1 \mathrm{~cm}$ ) and increased fruit yield/plant without significant differences with Vitavax ${ }^{\circledR}$-200when compared to untreated control. T. harzianum recorded the highest fruit yield ( $235 \mathrm{~g} / \mathrm{plant})$ followed by Vitavax ${ }^{\circledR}-200$ (228.5 g/plant) with no significant differences. The use of the bio-control agent would be useful and recommended to reduce environmental pollution that resulted from chemical fungicides. 
Table. (2): Efficacy of tested treatments in the management of Fusarium wilts of tomato under greenhouse conditions.

\begin{tabular}{lccc}
\hline \multicolumn{1}{c}{ Treatments } & $\begin{array}{c}\text { Plant height } \\
\text { (cm) }\end{array}$ & $\begin{array}{c}\text { Disease incidence } \\
\text { Percentage }\end{array}$ & $\begin{array}{c}\text { Fruit yield } \\
\text { g/plant }\end{array}$ \\
\hline T. harzianum & $69.6^{\mathrm{a}}$ & $16.9^{\mathrm{b}}$ & $235.0^{\mathrm{a}}$ \\
Vitavax $^{\circledR}-200(0.15 \%)$ & $62.4^{\mathrm{b}}$ & $11.3^{\mathrm{a}}$ & $228.5^{\mathrm{a}}$ \\
Inoculated control (with pathogen) & $48.3^{\mathrm{d}}$ & $59.6^{\mathrm{d}}$ & $123.5^{\mathrm{c}}$ \\
Healthy control (without pathogen) & $54.5^{\mathrm{c}}$ & $21.4^{\mathrm{c}}$ & $183.5^{\mathrm{b}}$ \\
\hline
\end{tabular}

- Mean of six replications

- In a column, means followed by the same letters are not significantly different at the $5 \%$ level by DMRT.

The potential of Trichoderma species as bio-control agents against various plant diseases has been reported by several workers (Wells et al., 1972 and Sharon et al., 2001). In the present investigation, fungal antagonist $T$. harzianum caused highly significant reduction in tomato wilt incidence under in vitro and in vivo conditions. The inhibitory effect of these bio-agents against tested pathogen was probably due to competition and/or antibiosis.

In vitro effectiveness of $T$. harzianum against species of Fusarium have been reported (Padmadaya and Reddy 1996). The antagonist Trichoderma harzianum, $T$. coningi and $T$. viride were reported to be equally antagonistic to F. udum in vitro (Bahatnagar, 1986). Sivan and Chet, (1987) reported that Trichoderma spp. successfully controlled Fusarium spp. on cotton, wheat and muskmelon. Sesame seeds treated with three isolates of $T$. viride reduced the pre- and post-emergence damping off caused by $R$. solani and $F$. oxysporum $f$. sp. sesame under pot culture and field conditions.

In the present investigation, the plant height and fruit yield were also increased in $T$. harzianum treated plants. Similar results on increased plant growth due to application of Trichoderma gamsii in cereals and legume crops were reported (Rinu et al., 2013). The increase in plant growth might be associated with secretion of auxins, gibberellins and cytokinins.

The increase in biomatter production may be due to the production of plant growth promoters or through indirect stimulation of nutrient uptake and by producing siderophore or antibiotics to protect plants from deleterious rhizosphere organisms. Therefore, the antagonist $T$. harzianum is chosen to be the most promising bio-control agent for F. oxysporum f. sp. lycopersici. On the base of present study the bio-agents of fungi, might be exploited for sustainable disease management programs to save environmental risk (Margaret et al., 2011 and Sundaramoorthy and Balabaskar, 2013).

Finally, the present evaluation thus gave clear indication that $T$. harzianum is effective and virulent antagonist, which can be effectively used in the management of tomato wilt. Combination of seedling dip and soil application appears to be most effective. 


\section{REFERENCES}

Agrios, G.N. 1988. Plant Pathology. $3^{\text {rd }}$ Edition. New York : Academic Press.

Agrios, G.N. 2005. Plant Pathology. $5^{\text {th }}$ ed. Academic Press, London.

Anonymous, 2007. Season and Crop report of Tamil Nadu, Department of Economics and Statistics, Chennai.

Bahatnagar, H. 1986. Influence of environmental condition on antagonistic activity of Trichoderma spp. against Fusarium udum. Indian Journal of Mycology and Plant Pathology. 26: 58-63.

Baker, R. 1989. Improved Trichoderma spp. for promoting crop productivity. Trends Biotechnol. 7:34-38.

Bell, D.K., H.D. Well and C.R. Markham. 1982. In vitro antagonism of Trichoderma species against six fungal plant pathogens. Phytopathol., 72: 379-382.

Besri, M. 1982. Solar heating (solarizatlon) of tomato supports for control of Didymella lycopersic stem canker. (Abstr.). Phytopathol., 72: 939.

Biswas, K.K. and N.D. Das. 1999. Biological control of pigeon pea wilt caused by Fusarium udum with Trichoderma spp. Ann. Plant Protect. Sci., 7(1): 46-50.

Cal, A., I. Larena, P. Sabuquillo and P. Melgarejo. 2004. Biological control of tomato wilts. Recent Res. Devel. Crop Sci., 1: 97-115.

Chet, I., Y. Elad and Z. Sadowsky. 1987. Scanning electron microscopical observations of early stages of interaction of Trichoderma harzianum and Rhizoctonia solani. Trans. Br. Mycol. Soc. 88:257-263.

Elad, Y. and A. Kapat. 1999. The role of Trichoderma harzianum protease in the biocontrol of Botrytis cinerea. Europ. J. Plant Pathol., 105: 177-189.

Gomez, K.A. and A.A. Gomez. 1984. Statistical Procedures for Agricultural Research. John Wiley and Sons, New York, USA.

Harman, G.E. 2000. Myths and dogmas of biocontrol. Changes in perceptions derived from research on Trichoderma harzianum T-22. Plant Dis., 84:377-393.

Hayes, W.J. and E.R. Laws. 1991. Handbook of Pesticide Toxicology, Vol.1. Academic Press, India.

Kormaik, P.P. and A.C. McGraw. 1982. Quantification of vesicular arbuscular mycorrhizae in plant roots. In: Methods and principles of mycorrhizal research. Schenick N. C., editor. American Phytopathological Society. St. Paul: pp. 37-45.

Margaret W. Mwangi, Ethel O. Monda, Sheila A. Okoth and Joyce M. Jefwa. 2011. Inoculation of tomato seedlings with Trichoderma harzianum and arbuscular mycorrhizal fungi and their effect on growth and control of wilt in tomato seedlings. Braz J Microbiol. 2011 Apr-Jun; 42(2): 508-513.

Morsy, E.M., K.A. Abdel-Kawi and M.N.A. Khalil. 2009. Efficacy of Trichoderma virideand Bacillus subtilisas biocontrol agents against Fusarium solani on tomato plants. Egyptian J. Plant Pathol., 37(1): 47-57.

Padmadaya, B. and H.R. Reddy. 1996. Screening of Trichoderma spp. against Fusarium oxysporum f. sp. lycopersici causing wilt on tomato. Indian $\mathrm{J}$. Mycol. Plant Pathol., 26: 288-290.

Ramezani, H. 2008. Biological control of root-rot of eggplant caused by Macrophomina phaseolina. Amer. Euras. J. Agric. Environ. Sci., 4(2): 218220. 
Ramezani, H. 2009. Efficacy of fungal and bacterial bioagents against Fusarium oxysporum f. sp. cicerion chickpea. Plant Protec. J., 1: 108-113.

Rinu, K., P. Sati and A. Pandey. 2013. Trichoderma gamsii (NFCCl 2177): A newly isolated endophytic, psychrotolerant, plant growth promoting, and antagonistic fungal strain. JBM. doi: 10.1002/jobm. 201200579.

Sabalpara, A.N., J. Priya, R.R. Waghunde and J.P. Pandya. 2009. Antagonism of Trichoderma against sugarcane wilt pathogen (Fusariumm oniliformae), Amer. Euras. J. of Agric. Environ. Sci., 3(4): 637-638.

Sharon, E., M. Bar-Eyal, I. Chet, A. Herra-Estrella, O. Kleified and Y. Spigel. 2001. Biological control of the root-knot nematode Meloidogyne javanica by Trichoderma harzianum. Phytopathol., 91: 687- 693.

Sivan, A. and I. Chet. 1987. Biological control of Fusarium crown rot of tomato by Trichoderma harzianum under field condition. Plant Disease, 71: 589592.

Spalding, D.H. and W.F. Reeder. 1974. Post-harvest control of snap bean pods with heated and unheted chemical dips. Pl. Dis. Reptr., 58: 59-62.

Srinon, W., K. Chuncheen, K. Jirattiwarutkul, K. Soytong and S. Kanokmedhakul. 2006. Efficacies of antagonistic fungi against Fusarium wilt disease of cucumber and tomato and the assay of its enzyme activity. J. Agric. Technol., 2(2):191- 201.

Sundaramoorthy, S. and P. Balabaskar. 2013. Biocontrol efficacy of Trichoderma spp. against wilt of tomato caused by Fusarium oxysporum $\mathrm{f}$. sp. Lycopersici. J. App. Biol. Biotechnol., 1(3) : 036-40.

Vincent, J.M.1927. Distribution of fungal hyphae in the presence of certain inhibition. Nature. 159: 50.

Waudo, S.W., P.O. Owino and M. Kuria.1995. Control of Fusarium wilt of tomatoes using soil amendments. East Afr. Agric. For. J. 60:207-217.

Wells, H.D., D.K. Bell and C.A. Jaworski.1972. Efficacy of Trichoderma harzianumas a biocontrol for Sclerotium rolfsii. Phytopathol., 62: 442-447. 


$$
\text { الملخص العربى }
$$

\title{
فعالية التراكوديرما هارزيانم كعنصر مكافحة حيوية مقارنة مع مبيد فطرى كيميائى
} تقليدى لمكافحة ممرض التربة فيوزاريم اكسبيسبوريم الأى يصيب نباتات الطماطم

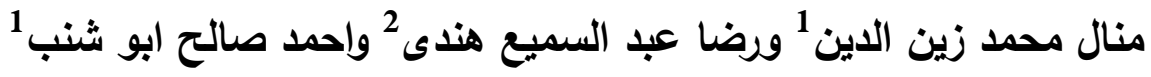

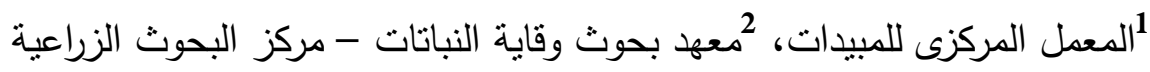

تم تتفيذ التجارب المعملية وفى الصوب للتحقق ومقارنة كفاءة عنصر مكافحة حيوية لممرضات التربة (التراكوديرما هارزيانم) مع مبيد فطرى تقليدى فيتافاكس-200. وقد أوضحت النتائج أن التراكوديرما كانت أكثر كفاءة من مبيد الفيتافاكس فى تنبيط النمو الفطرى بالتجربة المعلية. وخلال تجربة نقع الجذور ومعاملة التربة فى الحقل تحت ظروف الصوبة تبين أن المبيد الفطرى فيتافاكس-200 كان أكثر كفاءة من التراكوديرما المختبرة حيث سجل أقلى نسبة إصابة بالذبول لنباتات الطماطم مقارنة بالكنترول الغير معامل، وبالقياسات النباتية كانت نباتات الطماطم لنان

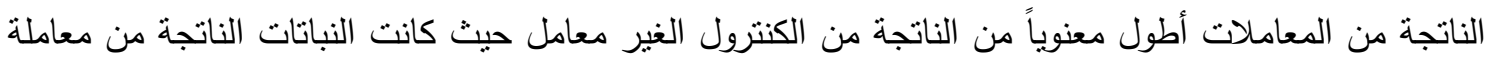

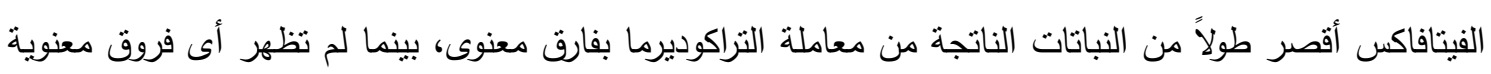

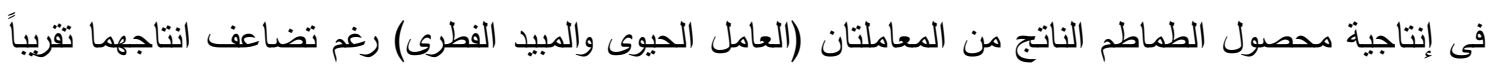
عن الكنترول (غير المعامل). 